\title{
PREVALENCE OF SOME FOOD POISONING BACTERIA ISOLATED FROM MILK AND SOME MILK PRODUCTS IN KAFR EL-SHEIKH GOVERNORATE
}

\author{
Ahmed, H. F. ${ }^{a}$, Ibrahim Eldesouky ${ }^{b^{*}}$ and Rashed, Amira A. \\ ${ }^{a}$ Food Control Department, Fac. Vet. Med., Kafrelsheikh Univ., Egypt

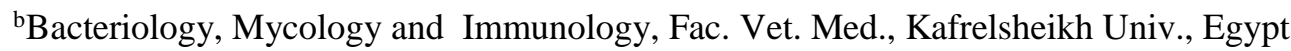

\section{ABSTRACT}

A total of two hundred samples (100 milk and 50 each of kareish cheese and ice-cream) were collected from different localities in Kafrelsheikh Governorate for detection of some food poisoning bacteria. The results revealed that S.aureus was detected in 13, 14 and $12 \%$ with mean counts of $5.8 \times 10^{4}, 11.9 \times 10^{4}$ and $3.3 \times 10^{4}$. While, E.coli was detected in 11, 14 and $14 \%$ with mean counts of $2.8 \times 10^{4}, 11 \times 10^{4}$ and $3.6 \times 10^{4}$ in milk, kareish cheese and ice cream samples, respectively. Salmonella spp. was not detected in any of the examined samples. The results concluded that milk and dairy products may at times suitable for supporting the growth of these organisms and subsequently be responsible for food poisoning. The public health significance of the isolated organisms was discussed.

\section{INTRODUCTION}

Food poisoning is a common, yet distressing and sometimes lifethreatening problem for millions of people throughout the world. People infected with food-borne organisms may be symptom-free or may have symptoms ranging from mild intestinal discomfort to severe dehydration and bloody diarrhea. Depending on the type of infection, people can even die as a result of food poisoning (Trickett, 1980). 
Milk and dairy products are considered as the most perfect food for human from birth to senility. They are not only having good sensory properties, but also containing all nutrients for the body which can prevent or reduce risks of many nutritional deficiency diseases (Marshall et al., 2003). Unfortunately, milk produced under superior hygienic condition yet various microorganisms which may gain access during production and storage may grow and affect the quality and safety of such milk (Marthand Steele, 2001).

S.aureus is one of the most important reasons for bacterial food poisoning. Staphylococcal food poisoning is due to the absorption of staphylococcal enterotoxins preformed in the food. From 1991 to 2005 , $S$. aureus poisoning cases counted about $17.5 \%$ of the total bacterial induced food-poisoning cases in Taiwan (Chiang et al., 2008). Milk and milk products are common vehicles of S.aureus food poisoning (Jorgensen et al., 2005).

E.coli has become recognized as a serious foodborne pathogen and has been associated with numerous outbreaks in the UK, Japan and USA (Scotter et al., 2000). E.coli includes a variety of different types that range from a virulent commensally strains that are present in the normal intestinal flora to highly virulent strains that cause a variety of severe infections in both humans and animals. The pathogenicity of E.coli is considered to be mainly determined by specific virulence factors such as adhesions, invasions, toxins and capsule (Kaper et al.,2004).

Salmonella is a bacterial infection that can be passed on to humans from domestic and wild animals, including poultry, pigs, cattle, and pets. Many strains of Salmonella are the principal pathogens implicated in human food-borne illnesses. But most often, it is caused by drinking

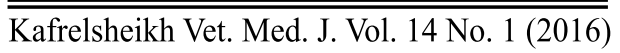


unpasteurized milk(Majowiczet al., 2010 and Hendriksenet al., 2011). They cause illness by means of infection, as they multiply in the small intestine, colonizing and subsequently invading the intestinal tissues, producing an enterotoxin and causing inflammatory reaction and diarrhea (I. C. M. S. F., 2006).

As information about distribution of different food poisoning organisms in Kafr EL-Sheikh governorate would help in the design of efficient therapeutic approaches and improvement of control measure. Therefore, the objective of this study was planned to determine the prevalence of some food poisoning organismsin milk and some milk products sold in Kafr EL-Sheikh governorate, Egypt.

\section{MATERIALS AND METHODS}

This study was carried out with two hundred samples (100 milk and 50 each of kareish cheese and ice-cream) collected from different localities in Kafr El-sheikh Governorate during January to December 2015. Samples were transferred to the laboratory to be examined bacteriologically.

\section{Preparation of serial dilutions (A.P.H.A., 1992):}

Raw Milk: $11 \mathrm{ml}$ of each milk sample was added to $99 \mathrm{ml}$ sterile peptone water (1\%) then thoroughly mixed to obtain $1 / 10$ dilution, from which 10 fold serial dilutions were prepared.

Ice cream: Samples were kept in thermostatically controlled water bath at $44^{\circ} \mathrm{C}$ for not more than 15 minutes with periodical shaking till melting before examined. Each sample was then thoroughly mixed using sterile stirrer. $11 \mathrm{ml}$ of each sample was added to $99 \mathrm{ml}$ sterile peptone water (1\%) to obtain 1/10 dilution, from which 10 fold serial dilutions were prepared. 
Kareish cheese: $11 \mathrm{~g}$ of each sample was transferred to sterile morter, and $99 \mathrm{ml}$ of sterile $0.1 \%$ peptone water was added and mixed to obtain $1 / 10$ dilution, from which 10 fold serial dilutions were prepared.

Enumeration, isolation and identification of S.aureus and E.coli: From the already prepared serial dilutions, $0.1 \mathrm{ml}$ of each dilution was plated on the surface of Baried Parker agar for S.aureus and Eosin Methylene Blue agar (E.M.B) for E.coli and evenly distributed. The plates were incubated at $37^{\circ} \mathrm{C}$ for 48 hours. The shiny black colonies surrounded by halo zone were counted as S.aureus; while grayish and shiny colonies were counted as E.coli (Bailly and Scott (1998). Bacterial isolates were sub-cultured on slope agar for further identification according to Quinn et al. (2011).

\section{Isolation of Salmonella:}

Twenty five $\mathrm{g}$ or $\mathrm{ml}$ of each prepared sample was aseptically added to $225 \mathrm{ml}$ buffered peptone water, thoroughly mixed and incubated for $24 \mathrm{~h}$. at $37^{\circ} \mathrm{C}$. From the resultant pre-enrichment culture, $1 \mathrm{ml}$ was inoculated into sterile tubes containing $10 \mathrm{ml}$ of Rappaport-Vassiliadis broth and incubated at $41.5^{\circ} \mathrm{C} \pm 1{ }^{\circ} \mathrm{C}$ for $24 \mathrm{~h} \pm 3 \mathrm{~h}$. before streaking onto Xylose-Lysine Deoxycholate agar (XLD) as recommended by $\boldsymbol{I S O}$ (2002). The plates were incubated aerobically at $37^{\circ} \mathrm{C}$ for $24-48 \mathrm{~h}$. Suspected colonies were described for their morphological characteristic appearance, followed by Gram staining before being transferred into slope agar to be subjected for further identification according to Quinn et al. (2011). 


\section{RESULTS}

Table (1): Incidence of S.aureus, E. coli and Salmonella in the examined raw milk, kareish cheese and ice cream samples.

\begin{tabular}{|c|c|c|c|c|c|c|c|}
\hline \multirow[t]{2}{*}{ Products } & \multirow{2}{*}{$\begin{array}{c}\text { No. Of } \\
\text { examined } \\
\text { samples }\end{array}$} & \multicolumn{2}{|c|}{$\begin{array}{c}\text { Salmonella } \\
\text { Positive samples } \\
\end{array}$} & \multicolumn{2}{|c|}{$\begin{array}{c}\text { S. ureus } \\
\text { Positive samples }\end{array}$} & \multicolumn{2}{|c|}{$\begin{array}{c}\text { E.coli } \\
\text { Positive samples } \\
\end{array}$} \\
\hline & & No. & $\%$ & No. & $\%$ & No. & $\%$ \\
\hline Milk & 100 & $\overline{0}$ & 0 & 13 & 13 & 11 & 11 \\
\hline Kareish cheese & 50 & 0 & 0 & 7 & 14 & 7 & 14 \\
\hline Ice-cream & 50 & 0 & 0 & 6 & 12 & 7 & 14 \\
\hline Total & 200 & $\overline{\mathbf{0}}$ & $\overline{0}$ & 26 & 13 & 25 & 12.5 \\
\hline
\end{tabular}

Table (2): Statistical analytical results of bacterial counts (cfu/ml or $\mathrm{g}$ ) of the examined milk, Kareish cheese and ice cream samples.

\begin{tabular}{|c|c|c|c|c|c|c|}
\hline \multirow{2}{*}{ Products } & \multicolumn{3}{|c|}{ S.aureus } & \multicolumn{3}{|c|}{ E.coli } \\
\hline & Minimum & Maximum & Mean \pm SE & Minimum & Maximum & Mean \pm SE \\
\hline Raw milk & $1.1 \times 10^{4}$ & $1.89 \times 10^{5}$ & $5.8 \times 10^{4} \pm 4.8 \times 10^{3}$ & $1.2 \times 10^{4}$ & $1.8 \times 10^{5}$ & $2.8 \times 10^{4} \pm 1.5 \times 10^{3}$ \\
\hline Kareish cheese & $3.6 \times 10^{4}$ & $2.86 \times 10^{5}$ & $11.9 \times 10^{4} \pm 1.29 \times 10^{4}$ & $1.3 \times 10^{4}$ & $2.04 \times 10^{5}$ & $11 \times 10^{4} \pm 11.3 \times 10^{3}$ \\
\hline Ice-cream & $1.2 \times 10^{4}$ & $6.1 \times 10^{4}$ & $3.3 \times 10^{4} \pm 2.6 \times 10^{3}$ & $1.3 \times 10^{4}$ & $8.1 \times 10^{4}$ & $3.6 \times 10^{4} \pm 3.4 \times 10^{3}$ \\
\hline
\end{tabular}

Table (3): Frequency distribution of the examined samples based on their $S$. aureus count.

\begin{tabular}{|c|c|c|c|c|c|c|c|c|c|c|}
\hline \multirow{3}{*}{ Products } & \multicolumn{2}{|c|}{ Positive samples } & \multicolumn{8}{|c|}{ S.aureus/ $\mathrm{ml}$ or $\mathrm{g}$} \\
\hline & \multirow{2}{*}{$\begin{array}{l}\text { No. } \\
\text { No. }\end{array}$} & \multirow{2}{*}{$\frac{\%}{\%}$} & \multicolumn{2}{|c|}{$<10^{4}$} & \multicolumn{2}{|c|}{$10^{4}-<5 \times 10^{4}$} & \multicolumn{2}{|c|}{$5 \times 10^{4}-<10^{5}$} & \multicolumn{2}{|c|}{$10^{5}-<5 \times 10^{5}$} \\
\hline & & & No. & $\%$ & No. & $\% \bullet$ & No. & $\%$ & No. & $\%$ \\
\hline Raw milk & 13 & 13 & 0 & 0 & 7 & 53.8 & 4 & 30.8 & 2 & 15.4 \\
\hline Kareish cheese & 7 & 14 & 0 & 0 & 1 & 14.2 & 3 & 42.9 & 3 & 42.9 \\
\hline Ice-cream & 6 & 12 & 0 & 0 & 5 & 83.3 & 1 & 16.7 & 0 & 0 \\
\hline
\end{tabular}

-: The percentages were calculated according to the number of positive samples.

Table (4): Frequency distribution of the examined samples based on their $E$. coli count.

\begin{tabular}{|c|c|c|c|c|c|c|c|c|c|c|}
\hline \multirow{3}{*}{ Products } & \multicolumn{2}{|c|}{ Positive samples } & \multicolumn{8}{|c|}{ E.coli/ ml or g } \\
\hline & \multirow{2}{*}{$\begin{array}{l}\text { No. } \\
\text { No. }\end{array}$} & \multirow{2}{*}{$\%$} & \multicolumn{2}{|c|}{$<10^{4}$} & \multicolumn{2}{|c|}{$10^{4}-<5 \times 10^{4}$} & \multicolumn{2}{|c|}{$5 \times 10^{4}-<10^{5}$} & \multicolumn{2}{|c|}{$10^{5}-<5 \times 10^{5}$} \\
\hline & & & No. & $\% \bullet$ & No. & $\% \bullet$ & No. & $\% \bullet$ & No. & $\% \bullet$ \\
\hline Raw milk & 11 & 11 & 0 & 0 & 4 & 36.4 & 4 & 36.4 & 3 & 27.2 \\
\hline Kareish cheese & 7 & 14 & 0 & 0 & 2 & 28.5 & 2 & 28.5 & 3 & 43 \\
\hline Ice-cream & 7 & 14 & 0 & 0 & 5 & 71.4 & 2 & 28.6 & 0 & 0 \\
\hline
\end{tabular}

•: The percentages were calculated according to the number of positive samples.

$\overline{\text { Kafrelsheikh Vet. Med. J. Vol. } 14 \text { No. } 1 \text { (2016) }}$ 


\section{DISCUSSION}

Naturally, S.aureus isolates are inhabitants of mucous epithelia and skin of human, dairy cattle and other mammalians (Chu et al., 2012), and spread by virtue of milker's hand/milking machines (Seki et al., 1998). It is one of the most important reasons for bacterial food poisoning, which results from ingestion of toxins produced by toxigenic strains of S.aureus. Enterotoxins are groups of single chain protein, resistant to high temperature and proteolytic enzymes. The enterotoxigenic strains of S.aureus produce several types of enterotoxins which can cause symptoms of intoxications such as vomiting, diarrhea and abdominal cramping (Korpysaet al., 2005).

Overall 200 samples examined, S.aureus was isolated from 13, 14 and $12 \%$ of milk, kareish cheese and ice cream samples, respectively with mean counts of $5.8 \times 10^{4} \pm 4.8 \times 10^{3}, 11.9 \times 10^{4} \pm 12.9 \times 10^{3}$ and $3.3 \times 10^{4} \pm 2.6 \times 10^{3}$ (Tables $1 \& 2$ ). The highest frequency distribution $(53.8 \%)$ lied within the range of $\left(10^{4}-<5 \times 10^{4}\right)$; $(85.8 \%)$ within the range of $\left(5 \times 10^{4}-<5 \times 10^{5}\right)$ and $(83.3 \%)$ within the range of $\left(10^{4}-<5 \times\right.$ $10^{4}$ ), respectively (Table 3). S.aureus is one of the most important pathogens that has received more attention due to its high incidence relatively to other organisms. Nearly similar results were obtained by Kruy et al. (2001); Hanaa(2008) and Mohammed (2009). Comparatively, lower values were declared by Rajeev and Amit (2010) and Mohammed et al. (2012). Higher findings were recorded by Saad (2013) and Saber (2013). S.aureus is one of the most prevalent bacteria in food poisoning in human(Chiang et al., 2008). In many countries, low degree contaminations by S.aureus are tolerated in most foodstuffs (up to $10^{3} \mathrm{cfu} / \mathrm{g}$ in raw milk cheeses, in France), as they are not considered a risk for public health (Le Loir et al., 2003). 
S.aureus enterotoxins (SEs) are produced during the exponential phase of S.aureus growth, With the quality being strain dependant . Typically, doses of SE that cause illness result when at least $10^{5}-10^{8}$ $\mathrm{cfu} / \mathrm{g}$ of are present (Seo and Bohach 2007; Montville and Matthews 2008).

None of the examined samples exceeded the infectious dose required for S.aureus food poisoning. Many S.aureus outbreaks were recorded due to consumption of milk, cheese and ice-cream (Hobbs and Roberts, 1987).

In recent years much attention has been paid toward E.coli because of its importance as an organism of true faecal origin with the possible existence of associated enteric pathogens. Commensal E.coli plays a dynamic role in the ecology of intestinal tract. The E.coli genome exhibits a high degree of heterogeneity; therefore these bacteria can be a commensal organism. On the other hand it can be also a dangerous pathogen causing intestinal or extra-intestinal infections. Shiga toxinproducing E.coli (STEC) are one of the most important foodborne pathogens essential for public health, responsible for serious outbreaks, hemorrhagic colitis, and the hemolytic-uremic syndrome (HUS) and the leading cause of acute renal failure. Cattle is a natural reservoir of STEC and the transmission of this pathogen to humans can occur through the direct contact with infected animals, foods of animal origin such as meat or unpasteurized milk or via water contamination (Etcheverría\&Padola, 2013). Also E.coli established to be among the etiological agents causing enteritis and several extra gastrointestinal diseases (Robertson, 1988). It is of major public health significance related to risk of introducing these bacteria to the food chain (Newell et al., 2010). 
E. coli was detected in 11, 14 and $14 \%$ of milk, kareish cheese and ice cream samples, respectively (Table 1). The E coli counts ranged from

$$
1.2 \times 10^{4}-1.8 \times 10^{5} ; 1.3 \times 10^{4}-2.04 \times 10^{5} \text { and } 1.3 \times 10^{4}-8.1 \times 10^{4}
$$

with mean counts of $2.8 \times 10^{4} \pm 1.5 . \times 10^{3}, 11 \times 10^{4} \pm 11.3 \times 10^{4}$ and $3.6 \times 10^{4} \pm 3.4 \times 10^{3}$, respectively (Table 2 ). The highest frequency distribution $(72.8 \%)$ lied within the range of $\left(10^{4}-<10^{5}\right)$; $(43 \%)$ within the range of $\left(10^{5}--<5 \times 10^{5}\right)$ and $(71.4 \%)$ within the range of $\left(10^{4}-5<\right.$ $10^{4}$ ) for milk, kareish cheese and ice cream samples, respectively (Table 4).E. coli is the most important coliform that has received more attention due to its high incidence relatively to other coliforms. Nearly similar results were obtained by Hassan (2008); Ahmed et al. (2009) and Maniruzzaman et al. (2010). Lower values were recorded by Rajeev and Amit (2010)and AboZeed (2014). While, relatively higher values were declared by Baraheemet al. (2007); Lingathurai and Vellathurai (2010) and Ahmed, Esraa (2012). None of the examined samples exceeded the infectious dose $\left(2.55 \times 10^{6}\right)$ required for $E$. coli food poisoning (Haas et al. 2000)

Salmonella spp. was not detected in any of the examined samples. (Table1). These results were in accordance with that reported by Mena (2011) and Abo Zeed(2014). But, it could be detected by Hassan (2008); Ahmedet al. (2009) and Mohammed et al. (2012). The presence of Salmonella spp. Indicated poor handling practices, sewage contamination, and the animal might be infected with mastitis and possibly from milk handlers (I. CM. S. F., 1996 and Yuen et al. (2012). 
Salmonella have been considered to be the most important causal agents of foodborne illness throughout the world (Majowiczet al., 2010; Hendriksenet al., 2011). Raw milk is an important vehicle for Salmonella causing human infection.Hundreds of outbreaks in humans caused by milk products have primarily been due to the consumption of unpasteurized milk or cheeses made from unpasteurized milk (Bell and Kyriakides, 2002).

\section{CONCLUSION}

This study reports high prevalence of S.aureus and E.coli food poisoning organisms in Kafr EL-Sheikh governorate, Egypt. Therefore, special attention should be given to milk and dairy products, which act as invisible potential reservoir of these organisms that may constitute a public health hazard, and to guarantee safe consumption of raw milk and milk products.

\section{REFERENCE}

- Abo-Zeed, A. B. A. (2014): Prevalence of biological hazards in milk and some dairy products in Egyptian markets. Ph. D. Thesis, Fac. Vet. Med., Cairo Univ., Egypt.

- Ahmed, Esraa, G. H. (2012): Microbiological evaluation of soft cheeses sold in Beni-Suef Markets. Ph. D., Thesis, Fac. Vet. Med., Beni-Suef Uni.

- Ahmed, K.; Hussain, A.; Imran Qazalbash, M. A. and Hussain, W. (2009): Microbiological quality of ice cream sold in Gilgit Town. Pakistan J. of Nutrition, 8 (9) 1397-1400. 
- A. P. H. A. "American Public Health Association" (1992): Standard Methods for the Examination of Dairy Products. 16th Ed. American Public Health Association, New York.

- Bailly, W. R. and Scott, E. G. (1998): Diagnostic Microbiology. Atext book for the isolation and identification of pathogenicmicroorganisms. The C. V. Mosby Company, Saint Louis.

- Baraheem, O.; Hoda, A. E.; Wafaa, M. B. and Naglaa, F. G. (2007): Bacteriological Quality of Some Dairy Products in Alexandria. J Egypt Public Health Assoc., 82 (5) 99-109.

- Bell, C. and Kyriakides, A. (2002): Salmonella. A practical approach to the organism and its control in foods. $1^{\text {st }}$ Ed. Blackwell Science Ltd. 25 John Street, London WC1 N265.

- Chiang, Y. C., Wan,W. L., Chin, M. F., Wan, Y. P., Chien, S. C., \&Hau, Y. T. (2008): PCR detection of Staphylococcal enterotoxins (SEs) N, O, P, Q, R, U, and survey of SE types in Staphylococcus aureus isolates from food-poisoning cases in Taiwan. International Journal of Food Microbiology, 121, 66-73.

- Chu, C., C., Yu, Y., Lee \& Y. Su (2012): Genetically divergent methicillin resistant Staphylococcus aureus and sec-dependent mastitis of dairy goats in Taiwan. BMC Vet Res, $8,39$.

- Etcheverría, A. I. and Padola, N. L. (2013): Shiga toxin-producing Escherichia coli: Factors involved in virulence and cattle colonization. Virulence, 4, 366-372. 
- Haas CN, Thayyar-Madabusi A, Rose JB, Gerba CP (2000): Development of a doseresponse relationship for Escherichia coli O157:H7. International Journal of Food Microbiology 56(2-3): 153-159.

- Hanaa, E. A. A. and Abd-El-Rahman, A. A. (2008): Prevalence of some food-poisoning organisms in raw milk and ice-cream with special reference to enteropathogenicEscherichia coli. Assiut Vet. Med. J., 54 (117) 89 - 105.

- Hassan, M. A. A. (2008): Assessment of probable microbiological hazards in some dairy products. M. V. Sc. Thesis, Fac. Agriculture, Ain Shams Univ., Egypt.

- Hendriksen, R. S.; Vieira, A. R. and Karlsmose, S. (2011): Global monitoring of Salmonella serovar distribution from the World Health Organization Global Foodborne Infections Network Country Data Bank: results of quality assured laboratories from 2001 to 2007. Foodborne Pathog. Dis., 8: 887-900.

- Hobbs, B. C. and Roberts, D. (1987): Food poisoning and food hygiene. Edward Arnold, $5^{\text {th }}$ Ed., London.

- I. C. M. S. F. “International Commission on Microbiological Specification" (1996): International committee-on Microbiological Specification of Foods. Microorganisms in Foods, Microbiological

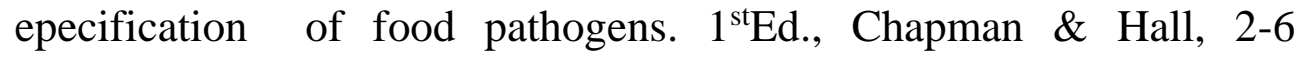
Boundary Row, London SE18 HN, UK. 
- I. C. M. S. F. “International Commission on Microbiological Specification"(2006): Microorganism in Foods, Microbial ecology of food commodities. $2^{\text {nd }}$ Ed. Kluwer Academics, Plenum Publishers. Londers, U. K.

- ISO “International Standardization Organization”(2002): Microbiology of food and animal feeding stuffs-horizontal method for the detection of salmonella spp.Fourth edition, Reference number ISO 6579:2002 (E).

- Jorgensen, H. J., Mork, T., Hogasen, H. R., \&Rorvik, L. M. (2005). Enterotoxigenic staphylococcus aureus in bulk milk in Norway.

- Kaper, J. B.; Nataro, J. P. and Mobely, H. L. T. (2004): Pathogenic E. coli. Nat. Rev. Microbiol. 2:123-140.

- Korpysa, W.; Rola, J. G. and Osek, J. (2005): Staphylococcal enterotoxins and their detection in milk and milk products. Medycyna Weterynaryjna, 61(6):633-636.

- Kruy, S. L.; Soares, J. L.; Ping, S. and Sainte-Marie, F. F. (2001): Microbiological quality of "ice, ice cream sorbet" sold on the streets of Phnom Penh. Food Technol. J. 94 (5) 411-414.

- Le Loir,Y.;Baron,F.and Gautier,M.(2003): Staphylococcus aureus and food poisoning. Genet. Mol. Res., 2 (1): 63-76.

- Lingathurai, S. and Vellathurai, P. (2010): Bacteriological quality and safety of raw cow milk in Madurai, South India. Webmed Central Microbiology, 1(1O):WMCOOIO29. 
- Majowicz, S. E.; Musto, J. and Scallan, E. (2010): International Collaboration on Enteric Disease 'Burden of Illness' Studies. The global burden of nontyphoidal Salmonella gastroenteritis. Clin. Infect. Dis., 50: 882-9.

- Maniruzzaman, M.; Khan, M. F. R.; Amin, M. M.; Paul, A. K. and Islam, M. (2010): Isolation and Identification of Bacterial Flora from Milk of Apparently Healthy Buffalo-Cows. Int. J. BioRes. 1(3): 13-16

- Marshall, T. A.; Levy. S. M.; Broffit, B.; Warren, J.; Eichenberger Gilmore, J. M.; Burns, T. L. and Stumbo, (2003): Dental cans and beverage consumption in young children. Pediatrics, 112 (3Ptl): e184-191.

- Marth, E. H and Steele, J. J. (2001): Applied dairy microbiology $2^{\text {nd }}$ Ed. Dekker, Am, Inc., USA.

- Mena, F. S. (2011): Sensory Evaluation and Microbial load of Ice cream. M.V.Sc. Thesis, Fac. Vet. Med., Cairo Uni.

- Mohammed, E. A. (2009): Prevalence of Gram positive bacteria in milk and some dairy products. Mv. Sc. Thesis, Fac. Vet. Med., Zagazig Uni.

- Mohammed, G. M. O, Koatb, E. E., El-Dahshan, H. A., Aideia, H. A. (2012): Occurrence of S. aureus, Salmonella species and Listeria monocytogenes in farms and markets milk. Fac. Vet. Med., Assiut Univ., Egypt, J., 58, 133. 
- Montville, T. J. and Mahws, K. R.(2008): FooD microbiolgoy :An intoduction. $2^{\text {nd }} \mathrm{Ed}$, ASM press, Washington D.C.

- Newell, D. G., Koopmans, M., Verhoef, L., Duizer, E., Aidara-Kane, A., Sprong, H., Opsteegh, M., Langelaar, M., Threfall, J. and Scheutz, F. (2010): Food-borne diseases. The challenges of 20 years ago still persist while new ones continue to emerge. Int. J. Food Microbiol., 139, S3-S15.

- Quinn, P. J., Markey, b. K., Leonard, F. C., Fitzpatrick, E. S., Fanning, S., \&Hartigan, P. J. (2011): Veterinary microbiology and microbial disease. 2nd Ed., wiley-blackwell, $j$ wiley and sons ltd publication, $U K$.

- Rajeev, K. and Amit P. (2010): Detection of E. coli and Staphylococcus in milk and milk products in and around Pantnagar. Vet. World., 3 (11) 495-496.

- Robertson, D. C. (1988): Pathoogenesis and Enterotoxins of diarrhoeagenic E. coli. In: Virulence mechanisms of bacterial pathogens (Ed). J. A. Roth. American Society for Microbiology, Washington, D. C.

- Saad, S. N. M. (2013): Public health importance of entero toxigenic Staphylococcus aureusisolated from milk and some milk products. $\mathrm{Ph}$. D., Fac. Vet. Med., Cairo Uni.

- Saber, A. A. E. (2013): Microbiological profile of some dairy products. Ph. D., Fac. Vet. Med., Alexandria Uni. 
- Scotter, S.; Aldridge, M. and Capps, K. (2000): Validation of method for the detection of E. coli O157:H7 in foods. Food Control,11: 85.

- Seki, K., Sakurada, J., Seong, H. K., Murai, M., Tachi, H., Ishii, H., \& Masuda, S. (1998): Occurrence of coagulase serotype among Staphylococcus aureus strains isolated from healthy individualsspecial reference to correlation with size of protein-A gene. MicrobiolImmunol., 42, 407-409.

- Seo KS, Bohach GA (2007): Staphylococcus aureus. Ch 22 In: Doyle MP, Beuchat LR (eds) Food microbiology: Fundamentals and frontiers. 3rd ed, ASM Press, Washington D.C., p. 493-518.

- Trickett, J. (1980): The prevention of food poisoning. Stanley Thornes Ltd., London.

- Yuen, S. K.; Yee, C. F. and Yin, F. H. (2012): Microbiological quality and the impact of hygienic practices on the raw milk obtained from the small-scale dairy farmers in Sabah, Malaysia. Int. J. Agricult. Food Sci., 2 (2):55-59. 